\title{
MOTAGILLA SIALIS.
}

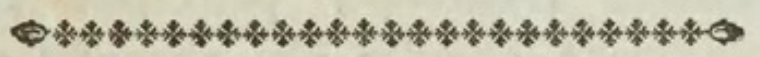

CHARACTER GENERICUS.

Rof rìm fubulatum, rectum: mandibulis fubæqualibus.

Nares obovatæ.

Lingua lacero-emarginata.

$$
\text { Lin. Syf. Nat. p. } 328 \text {, }
$$

CHARACTER SPECIFICUS, छc.

MOTACILLA cærulea, fubtus rufa.

MOTACILLA cærulea, fubtus tota rubra, abdomine albo.

$$
\begin{aligned}
& \text { Lin. Syft. Nat. p. } 336 . \\
& \text { Lin. Syft. Nat. Gmel. p. } 989 .
\end{aligned}
$$

RUBECULA CAROLINENSIS.

$$
\text { Briff. av. 3. p. } 423 \text {. }
$$

AVIS CAERULEA.

Kalm. it. 3. p. 30.

RUBECULA AMERICANA CÆRULEA.

Catefb. 1. p. $47 \cdot$ t. 47 .

C

Mota- 
Motacilla Sialis, eadem quafi magnitudine ac Motacilla Rubecula, aut paulo ampliore, Americam feptentrionalem inhabitat; præcipue Carolinam. Tota avis amoene cærulea eft, exceptis pectore et abdomine leviter rubentibus, remigibufque alarum primoribus apice fere nigricantibus. Roftrum nigrum. Pedes fufci. Infectis vefcitur more reliqui generis. 
ถู

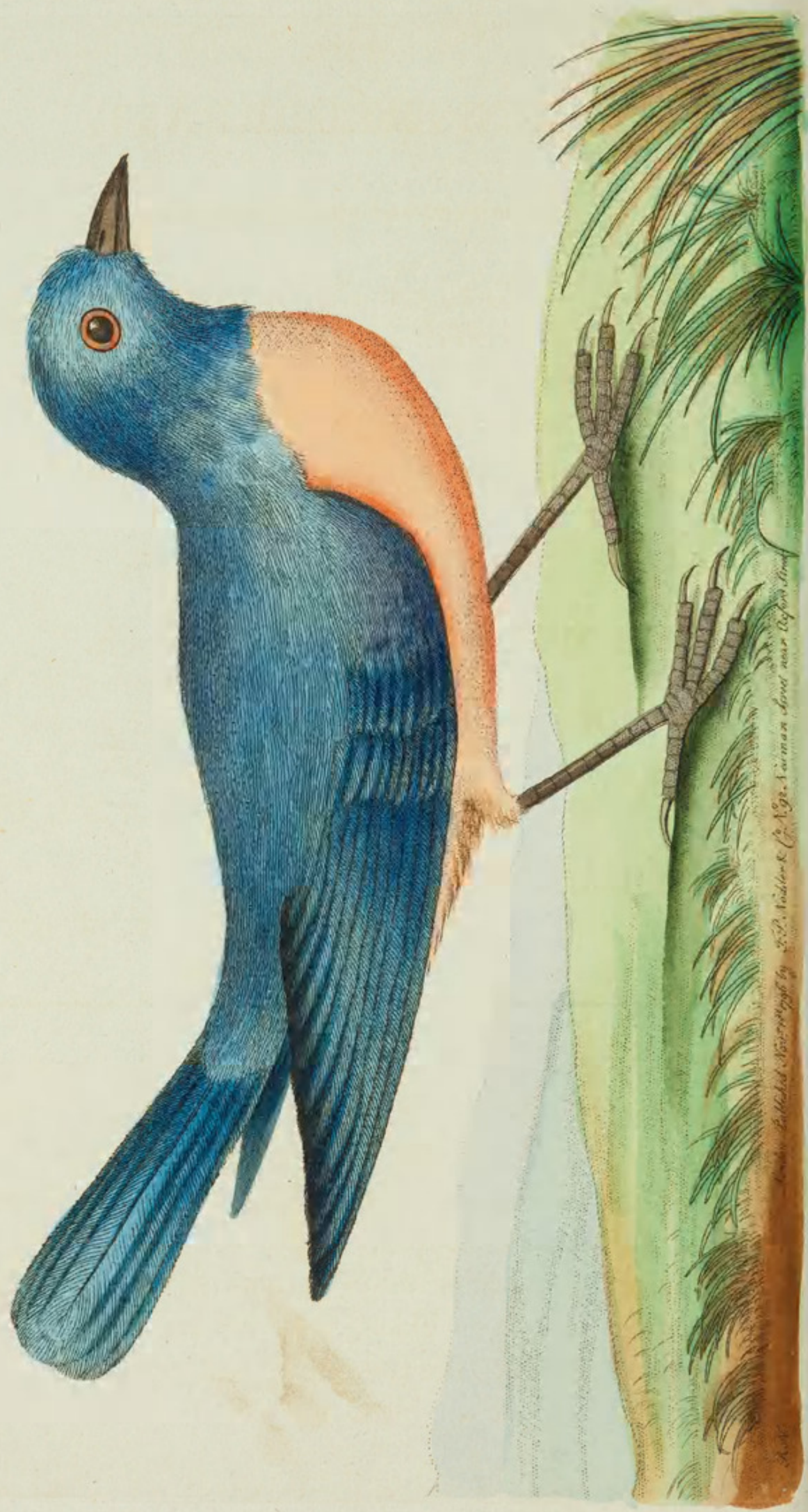




\section{BLUE REDBREAST.}

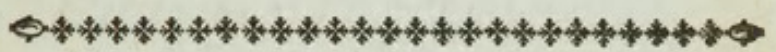

\section{GENERIC CHARACTER.}

Bill fubulate, ftrait; mandibles nearly equal. Noftrils nearly oval.

Tongue jagged or lacerated towards the tip.

$$
\text { SPECIFIC CHARACTER, E\%. }
$$

BLUE MOTACILLA, rufous beneath.

The BLUE WARBLER.

$$
\begin{aligned}
& \text { Lath. Syn. 4. p. } 446 . \\
& \text { Pennt. Arct. Zool. 2. No. } 282 .
\end{aligned}
$$

The BLUE REDBREAST.

Edw. 1. pl. 24.

This bird, which is about the fame fize with the common Redbreaft, or rather larger, is an inhabitant of North America, and is principally feen in Carolina : the whole bird is of a fine blue, the breaft and abdomen excepted, which are of a light red, and the tips of the principal wing-feathers, which are dufky; the bill is black, and the legs brown. It feeds on infects, like the reft of this genus.

$$
\mathrm{C}_{2}
$$




\section{$2 \mathrm{BHL}$ Biodiversity Heritage Library}

Shaw, George. 1796. "The Blue Redbreast, Motacilla sialis [PI. 261]." The Naturalist's Miscellany 8(LXXXVIII), https://doi.org/10.5962/p.310804.

View This Item Online: https://www.biodiversitylibrary.org/item/276320

DOI: https://doi.org/10.5962/p.310804

Permalink: https://www.biodiversitylibrary.org/partpdf/310804

\section{Holding Institution}

Museums Victoria

\section{Sponsored by}

Atlas of Living Australia

\section{Copyright \& Reuse}

Copyright Status: Public domain. The BHL considers that this work is no longer under copyright protection.

This document was created from content at the Biodiversity Heritage Library, the world's largest open access digital library for biodiversity literature and archives. Visit BHL at https://www.biodiversitylibrary.org. 